\title{
TEXT TRANSLATION METHOD BY CONSIDERING INFORMATION DISTRIBUTION IN THE FORM OF THEME-RHEME RELATION
}

\author{
Zulia Karini \\ STMIK AMIKOM Purwokerto \\ zulia@amikompurwokerto.ac.id
}

\begin{abstract}
This study will analyze the translation of sentences in the text by giving consideration to the distribution of information presented in the form of Theme-Rheme relation. First we will identify Themes - Rheme in the sentences in the text and will analyze the results of the translation. The theme is information that is prioritized in a sentence usually placed in the beginning of sentence, and Rheme is the proposed information. There are three types of Themes, namely Topical Theme, Interpersonal Theme, and Textual Theme. The object of discussion here is the Topical Themes, which are Themes relating to how the subject matter discussed in the clause or sentence is laid out. Topical themes are divided into two types: Marked Topical Theme and Unmarked Topical Theme. The analysis of Topical Themes are taken from a bilingual children's book entitled Sangkuriang from the publisher Nexx Media Inc., Bandung. Sangkuriang is one of the popular Indonesian folklore that tells of a very beautiful mother whose admirer is his own son. The text to be analyzed is part of the text that tells about the birth of Dayang Sumbi, the mother of Sangkuriang. From the result of the whole analysis, the source text consists of 10 Marked Topical Theme and Top 10 Unmarked Topical Theme. There are some Topical theme changes from the source text to the target text: a sentence with an Unmarked Topical Theme is translated into a sentence with a Marked Topical Theme, and vice versa. Based on the analysis of Topical Themes on the Source Text and Target Text it can be concluded that there are some sentences that have shifted Topical Themes. There have been some changes in information due to the shift in this Topical Theme, so it can be said that this translation is not good. At the end of the analysis is given an edit on the target text. The edit of this translation does not change the Topical Theme from the Source Text, so the subject matter in each sentence of the Target text is the same as the subject matter in each sentence of the Source Text.
\end{abstract}

Keywords: theme, rheme, source text, target text, translation

\section{Introduction}

In the practice of translation, the way information is distributed in text is often overlooked. The sentences in the text present the information, and the way the information is distributed can be identified. Information that is important is the old information that has been known to each other by the author and reader, which is usually placed on the front, while other information is new information only known by the author, which is usually placed later. The old information is identical to the Theme, and the new information is identical to Rheme. [1]

The theme is information that is prioritized in a sentence usually placed on the front, and Rheme is the proposed information. There is an opinion that since the Subject is the most important part, the Subject is always considered the same as the Theme. This is not the case. As will be explained below, Theme is only the same as Subject, if in front of Subject there is no other information. In other words, the Theme is the initial unit of a clause and the Rheme is the remainder. [2]

Theme is at clause rank the major textual system. The textual metafunction engenders resources for presenting interpersonal and ideational meanings as information organized into text. [3]

There are three types of themes, namely Topical Themes, Interpersonal Themes, and Textual Themes. The object of discussion here is the Topical Themes, which are Themes relating to how the subject matter discussed in the clause or sentence is laid out. Although Interpersonal Themes and Textual Themes are not subjected to discussion, the notions and examples will also be presented.

Topical themes are divided into two types: marked topical theme and unmarked topical theme. Sentence (1) below contains an 
example of a marked topical theme, while Sentence (2) contains an Unmarked Topical Theme. Each theme is in bold. Another part that is not in bold is Rheme. [4]

(1) From Keynes's perspective, the supply of money has a potentially important but indirect impact on the macro economy.

(2) A change in the money supply has an immediate effect on interest rates.

It is not difficult to identify Topical Themes. If there is no information in front of the Subject, the Subject serves as an Unmarked Topical Theme, as shown in Example (2). Apart from Interpersonal Themes and Textual Themes, if in front of the Subject there is information, it is possible that the information serves as a Marked Topical Theme, as shown in Example (1). In general, Topical Marked Themes are realized by Circumstances (adverbial of time, adverbial of place, adverbial of manner)

The activity of translating this analysis is an activity of arranging the translation of each Topical Theme by incorporating the Rheme translation located behind the Topical Theme.

\section{RESEARCH METHODOLOGY}

The method used in this research using descriptive qualitative research method that is a qualitative methodology as a research procedure that produces descriptive data in the form of written or oral words of persons and observable behavior [5]. Qualitative research is generally referred to as a descriptive qualitative approach. The results of this study contain excerpts from the data set that describes, describes, describes, classifies, analyzes, and interprets. This study spurred the emergence of a more real understanding than just serving numbers or frequency. The author emphasizes the notes with detailed, complete, and exhaustive description descriptions that describe the actual situation in order to support the presentation of data.

The translation method in the context of this study is how to do something, that is how to do the translation and methods related to a particular plan, namely the plan in the implementation of translation.

The implementation plan of translation is realized through three important stages of analysis, transfer and harmonization. There are two groups of methods of translation [6], namely (1) methods that provide em- phasis on the source language; and (2) methods that give emphasis to the target language. In this study, researchers analyzed the translation with Considering Information Distribution in The Form of Theme-Rheme Relations. The researcher then attempted to re-establish the exact meaning of the contextual meaning of the source language text. The final step is to do the researcher displayed text that has been edited from beginning to end.

The analysis of Topical Themes are taken from a bilingual children's book entitled Sangkuriang from the publisher Nexx Media Inc., Bandung. Sangkuriang is one of the popular Indonesian folk legends. It tells us a very beautiful mother whose admirer is her own son.

The text to be analyzed is part of the text that tells about the birth of Dayang Sumbi, the mother of Sangkuriang. To simplify the analysis, each end of a sentence in the source text will be numbered.

To identify the Themes in relation to Rheme, a diagram is created for all paragraphs on the reading

\section{Result and Discussion}

Source Text:

Hundreds of years ago, the Galuh kingdom in West Java, was ruled by a king of great wisdom namely Prabu Sungging Perbangkara ${ }^{(1)}$. Not only was he famous for his wisdom but also for his love of hunting(2). Once a month, along with some of his guards he explored the hunting grounds all over the kingdom from prairies, forests, hills, mountains, valleys to steep slopes(3).

One day when the king was going hunting, suddenly natured called(4). A toilet was certainly unavailable in such place(5). So he found himself bushes where a coconut laid under unnoticed and accidentally peed on the coconut $^{(6)}$. As a result, his urine got mixed with the coconut milk(7).

As soon as the king and his guards had left for the palace, a wild pig came to the bushes(8). It may have looked like most wild pigs(9), but it was actually Celeng Wayung Yang, a sow which was said to be the reincarnation of a Goddes(10). She was so thirsty so her eyes soon laid on the coconut ${ }^{(11)}$. What a coincidence(12)! Without thinking any further, she drank up all the coconut milk(13).

Months passed by(14) and Celeng Wayung Yang found herself pregnant(15). A few months later she gave birth to a baby $\operatorname{girl}^{(16)}$. 
Unlike her, the baby was amazingly humanlike(17)!

Not long after the baby was born, the king returned into the same forest $(18)$. While he was hunting, he was in such a shock to find a tiny baby(19). The baby looked so sweet and adorable that he fell in love with her(20). So he took her for his daughter and named her Dayang Sumbing(21).

Target Text:

Ratusan tahun silam, di kerajaan Galuh di Jawa Barat, hiduplah seorang raja arif bijaksana bernama Prabu Sungging Perbangkara. Selain karena kearifannya, Prabu Sungging Perbangkara juga dikenal gemar berburu. Sebulan sekali ia bersama beberapa orang pengawal pergi menjelajahi daerah-daerah perburuan di pelosok kerajaan. Dari padang rumput, hutan rimba, bukit, gunung, lembah, hingga lereng terjal, semuanya disatroni Sang Prabu.

Suatu ketika saat Sang Prabu sedang berburu di tengah hutan, ia tiba-tiba inging buang air kecil. Yang namanya di tengah hutan tentu saja tidak ada kamar kecil hingga Sang Prabu pergi mencari semak-semak untuk tempat 'hajat'nya. Tapi Sang Prabu tidak tahu kalau air seninya mengenai tempurung kelapa yang tergeletak di balik semak-semak itu. Walhasil sari kelapa di tempurung itu bercampur dengan air seni Sang Prabu.

Setelah Sang Prabu dan rombongannya kembali ke istana meninggalkan hutan itu, seekor babi hutan mendatangi semak-semak tempat Sang Prabu buang air kecil tadi. Sekilas babi hutan itu terlihat seperti babi hutan biasa tapi sebenarnya ia adalah Celeng Wayung Yang, titisan seorang dewi kahyangan. Matanya terpaut pada batok kelapa di sana. Kebetulan sekali! Aku sedang haus! Maka tanpa tedeng aling-aling ia pun segera menghabiskan air di batok kelapa itu.

Beberapa bulan berlalu, Celeng Wayang yang mendapati dirinya tengah mengandung dan akhirnya Celeng Wayang Yang melahirkan seorang bayi perempuan. Ajaibnya, bayi yang ia lahirkan berwujud bayi manusia!

Beberapa bulan kemudian, Sang Prabu kembali ke tempat di mana ia buang air dulu. Alangkah kagetnya ia saat menemukan bayi perempuan di tengah hutan. Tapi karena ia melihat bayi itu begitu mungil dan lucu, ia pun merasa sayang. Akhirnya Sang Prabu mengangkat bayi itu sebagai anaknya dan menamainya Dayang Sumbi.

\section{Topical Theme Analysis}

Parts in bold on source text and target text above are Topical Themes, and the rest are Rheme. Topical themes can be further subdivided into Marked Topical Themes and Unmarked Topical Themes.

Below is a list of Marked Topical Themes and Unmarked Topical Themes that have been identified from the source text above.

Marked Topical Themes (the realization is expressed in brackets):

Hundreds of years ago (adverb of time) : Ratusan tahun silam

Once a month (adverb of time) : Sebulan sekali

One day when the king was going hunting (Dependant clause: time) : Suatu ketika saat Sang Prabu sedang berburu di tengah hutan

As a result (adverb of manner) : Walhasil

As soon as the king and his guards had left for the palace (Dependant clause: time) : Setelah Sang Prabu dan rombongannya kembali ke istana meninggalkan hutan itu

Without thinking any further (adverb of manner) : tanpa tedeng aling-aling

A few months later (adverb of time) : Beberapa bulan berlalu

Unlike her (adverb of comparison) : Ajaibnya

Not long after the baby was born (adverb of time) : Beberapa bulan kemudian

While he was hunting (Dependant clause: time)

Unmarked Topical Theme (all are realized by the subject):

He : Prabu Sungging Perbangkara

A toilet : kamar kecil

He : sang Prabu

It : babi hutan itu

It : ia

She : aku

Months : beberapa bulan

Celeng Wayung Yang : Celeng Wayung Yang

The baby : bayi

He : Sang Prabu

Overall, the source text above consists of 10 Marked Topical Themes and 10 Unmarked Topical Themes. There is a Topical theme change from the source text to the target text: a sentence with an Unmarked Topical Theme is translated into a sentence with a Marked Topical Theme, and vice versa. The sentences that undergo Topical Theme changes are as 
follows:

\section{Sentence Number 2}

Source Text: Not only was he famous for his wisdom but also for his love of hunting.

Target Text:Selain karena kearifannya, Prabu Sungging Perbangkara juga dikenal gemar berburu.

In the source text, this phrase begins with a conjunction "not only" as a Textual Theme, and the information emphasized in this sentence is "he", occupying the Subject's position so that it has a function as an Unmarked Topical Theme. While in the Target Text, the information highlighted is no longer the Subject, but the Adverb of Manner 'selain karena kearifannya '. In the text of this translation, the Subject is no longer important. Thus, the information considered more important is the adverb of manner. The Topic theme has also changed to Marked Topical Theme.

In order not to change the Topical Themes, it is better for the Subject as information emphasized in this sentence to be translated first, so that the translation will be: "Dia tidak hanya terkenal karena kearifannya tetapi juga karena kegemarannya berburu".

\section{Sentence Number 5}

Source Text: A toilet was certainly unavailable in such place.

Target Text: Yang namanya di tengah hutan tentu saja tidak ada kamar kecil.

The information emphasized in the source sentence is 'a toilet' which functions as a subject and is placed on the front of the sentence without any other information in front of it, so it has a function as an unmarked topical theme. While in the words of target text, in front of the word 'toilet' (kamar kecil)' was given another information that highlighted by adverb of place 'di tengah hutan', so it has function as a marked topical theme. Thus, there is a Topical Theme change in the translation of this sentence. In order to maintain the function of a topical theme, in accordance with the source text of an unmarked topical theme, it should be in the target text that 'a toilet' is translated first, so the text would be: 'Toilet tentu saja tidak akan ada di tempat seperti ini.'
Sentence Number 9

Source Text: It may have looked like most wild

Target Text: Sekilas babi hutan itu terlihat seperti babi hutan biasa

In the source text, the topical theme occupies the function of the Unmarked Topical Theme. The subject 'it' is the most important information in this sentence. In the target text, the information emphasized is realized with adverb of time 'sekilas' which occupies the function as a Marked Topical Theme while 'it' which is translated into 'babi hutan' in target text occupies the function as Rheme. In order to avoid a shift in topical theme, it is better if the source text above is translated as follows: 'Babi hutan itu terlihat seperti babi hutan biasa'.

\section{Sentence Number 10}

Source Text: but it was actually Celeng Wayung Yang, a sow which was said to be the reincarnation of a Goddes

Target Text: tapi sebenarnya ia adalah Celeng Wayung Yang, titisan seorang dewi kahyangan

The subject 'it' in the source text above serves as an unmarked Topical Theme, because there is no other information in front of the subject. While in the target text, in front of the subject ' $i a^{\prime}$ there is other information that is more highlighted namely adverb of manner "sebenarnya", so that it occupies the function as Marked Topical theme, while the subject 'it' translated into ' $i a$ ' occupies the function as Rheme. In order for the subject 'it' RHEMEins an important information, preferably in the target text does not change the theme of the topic or in other words the translation is better to use unmarked topical theme, which is as follows: 'namun ia sebenarnya adalah Celeng Wayung Yang, titisan seorang dewi kahyangan.'

\section{Sentence Number 19}

Source Text: While he was hunting, he was in such a shock to find a tiny baby

Target Text: Alangkah kagetnya ia saat menemukan bayi perempuan di tengah hutan.

The subject matter discussed in the 
source text is realized with dependent clause of time: 'while he was hunting', placed in the front and functions as a Marked Topical Theme, while later information occupies a function as Rhema. In the target text, the information that matters is the subject of ' $i a$ ' which functions as an Unmarked Topical Theme. This makes the text of the translation seem to distort the important information contained in the source text. We recommend that the translation of source text above still emphasizes the time-dependent clause 'while he was hunting' as the subject matter discussed. The target text is better as follows: 'ketika Prabu Sungging Perbangkara sedang berburu, dia begitu kaget menemukan bayi mungil ditengah hutan.'

\section{Sentence Number 20}

Source Text: The baby looked so sweet and adorable that he fell in love with her

Target Text: Tapi karena ia melihat bayi itu begitu mungil dan lucu, ia pun merasa sayang.

The sentence in the source text above has an unmarked Topical Theme which is realized with the subject of 'the baby'. Whereas in the target text, the subject matter is no longer realized by the subject, but it is realized with the dependent clause of reason: 'karena ia melihat bayi itu begitu mungil dan lucu'. Its function changed to Marked Topical Theme. In order not to change the information, the Subject as an unmarked Topical Theme should be placed first in the source text, so the translation becomes: 'bayi itu begitu mungil dan lucu sehingga ia pun merasa sayang padanya'.

\section{Sentence Number 21}

Source Text: So he took her for his daughter and named her Dayang Sumbing

Target Text: Akhirnya Sang Prabu mengangkat bayi itu sebagai anaknya dan menamainya Dayang Sumbi.

In the source text above, the sentence begins with the conjunction as the Textual Theme, and the information emphasized in this sentence is 'he', occupying the position as the Subject so as to have the function as an unmarked Topical Theme. While in the target text, the information that is highlighted is no longer the Subject, but the adverb of time 'akhirnya'. In the text of this translation, the Subject is no longer important. Thus, the information considered more important is adverb of time. The Topical theme has also changed to Marked Topical Themes. The information thereafter occupies the function as Rheme. In order to avoid a shift in Topical Themes, it is better that the Subject as the information emphasized in this sentence is translated first, so the translation will be: 'Sang Prabu mengangkat bayi itu sebagai anaknya dan menamainya Dayang Sumbi.'

Based on the analysis of Topical Themes on source texts and target texts, it can be concluded that there are some sentences that have shifted Topical Themes. There are some changes to the information caused by this Topical Themes shift. The following is given an edit to the target text above. The edited ranslation does not shift or change the Topical Theme of the source texts, so the subject matter in each sentence of the target texts is the same as the subject matter in every sentence in the source texts.

\section{Edited Target Text:}

Ratusan tahun silam, di kerajaan Galuh di Jawa Barat, hiduplah seorang raja arif bijaksana bernama Prabu Sungging Perbangkara. Dia tidak hanya terkenal karena kearifannya tetapi juga karena kegemarannya berburu. Sebulan sekali ia bersama beberapa orang pengawal pergi menjelajahi daerah-daerah perburuan di pelosok kerajaan. Dari padang rumput, hutan rimba, bukit, gunung, lembah, hingga lereng terjal, semuanya disatroni Sang Prabu.

Suatu ketika saat Sang Prabu sedang berburu di tengah hutan, ia tiba-tiba inging buang air kecil. Toilet tentu saja tidak akan ada di tempat seperti ini hingga Sang Prabu pergi mencari semak-semak untuk tempat 'hajat'nya. Tapi Sang Prabu tidak tahu kalau air seninya mengenai tempurung kelapa yang tergeletak di balik semak-semak itu. Walhasil sari kelapa di tempurung itu bercampur dengan air seni Sang Prabu.

Setelah Sang Prabu dan rombongannya kembali ke istana meninggalkan hutan itu, seekor babi hutan mendatangi semak-semak tempat Sang Prabu buang air kecil tadi. Babi hutan itu 
terlihat seperti babi hutan biasa namun ia sebenarnya adalah Celeng Wayung Yang, titisan seorang dewi kahyangan. Matanya terpaut pada batok kelapa di sana. Kebetulan sekali! Aku sedang haus! Maka tanpa tedeng aling-aling ia pun segera menghabiskan air di batok kelapa itu.

Beberapa bulan berlalu, Celeng Wayang yang mendapati dirinya tengah mengandung dan akhirnya Celeng Wayang Yang melahirkan seorang bayi perempuan. Ajaibnya, bayi yang ia lahirkan berwujud bayi manusia!

Beberapa bulan kemudian, Sang Prabu kembali ke tempat di mana ia buang air dulu.
Ketika Prabu Sungging Perbangkara sedang berburu, dia begitu kaget menemukan bayi mungil ditengah hutan. Bayi itu begitu mungil dan lucu sehingga ia pun merasa sayang padanya. Sang Prabu mengangkat bayi itu sebagai anaknya dan menamainya Dayang Sumbi.

Theme - Rheme Analysis

To identify the Themes in relation to Rheme, a diagram for all paragraphs of the sourcetext is as follows:

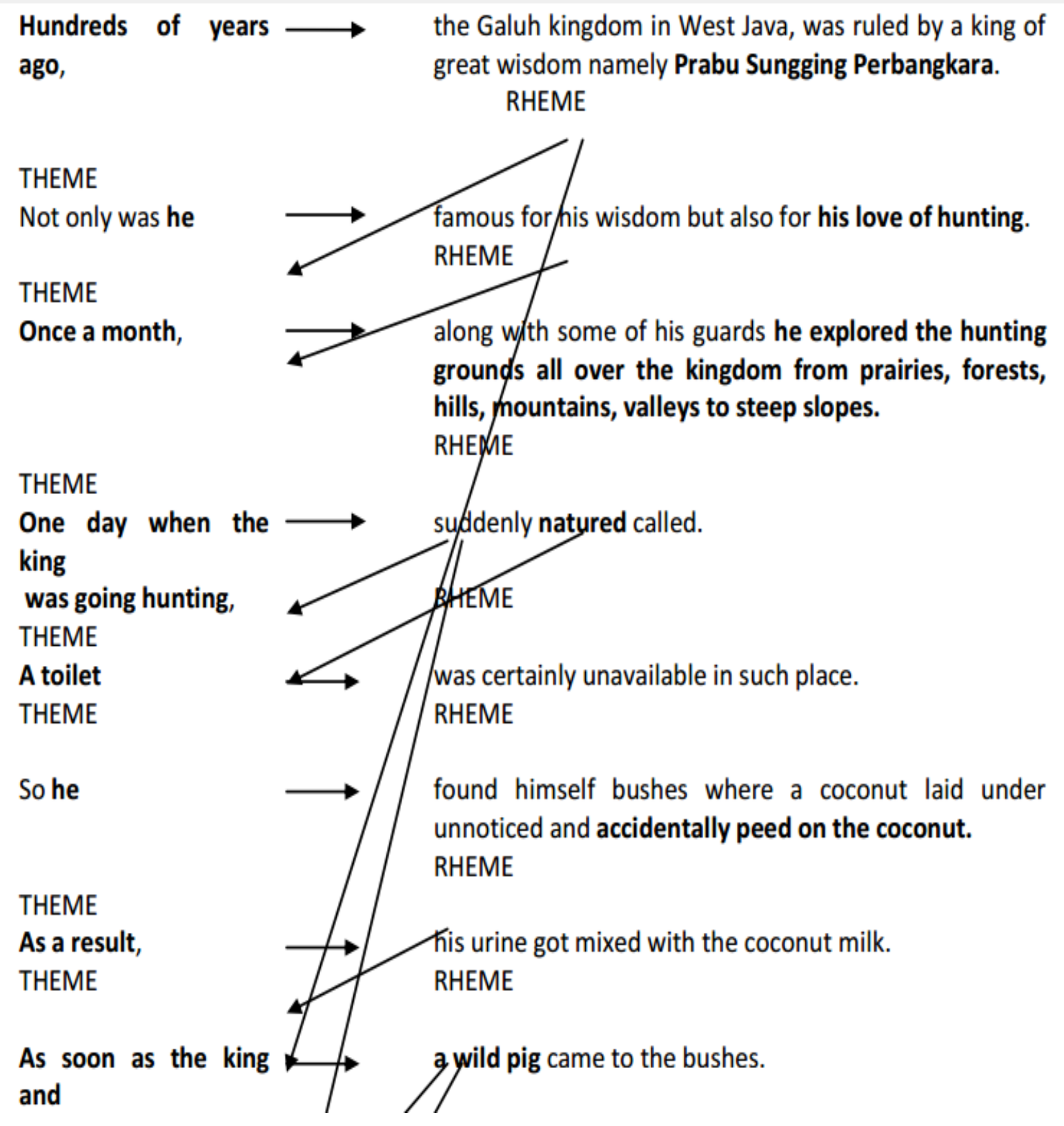



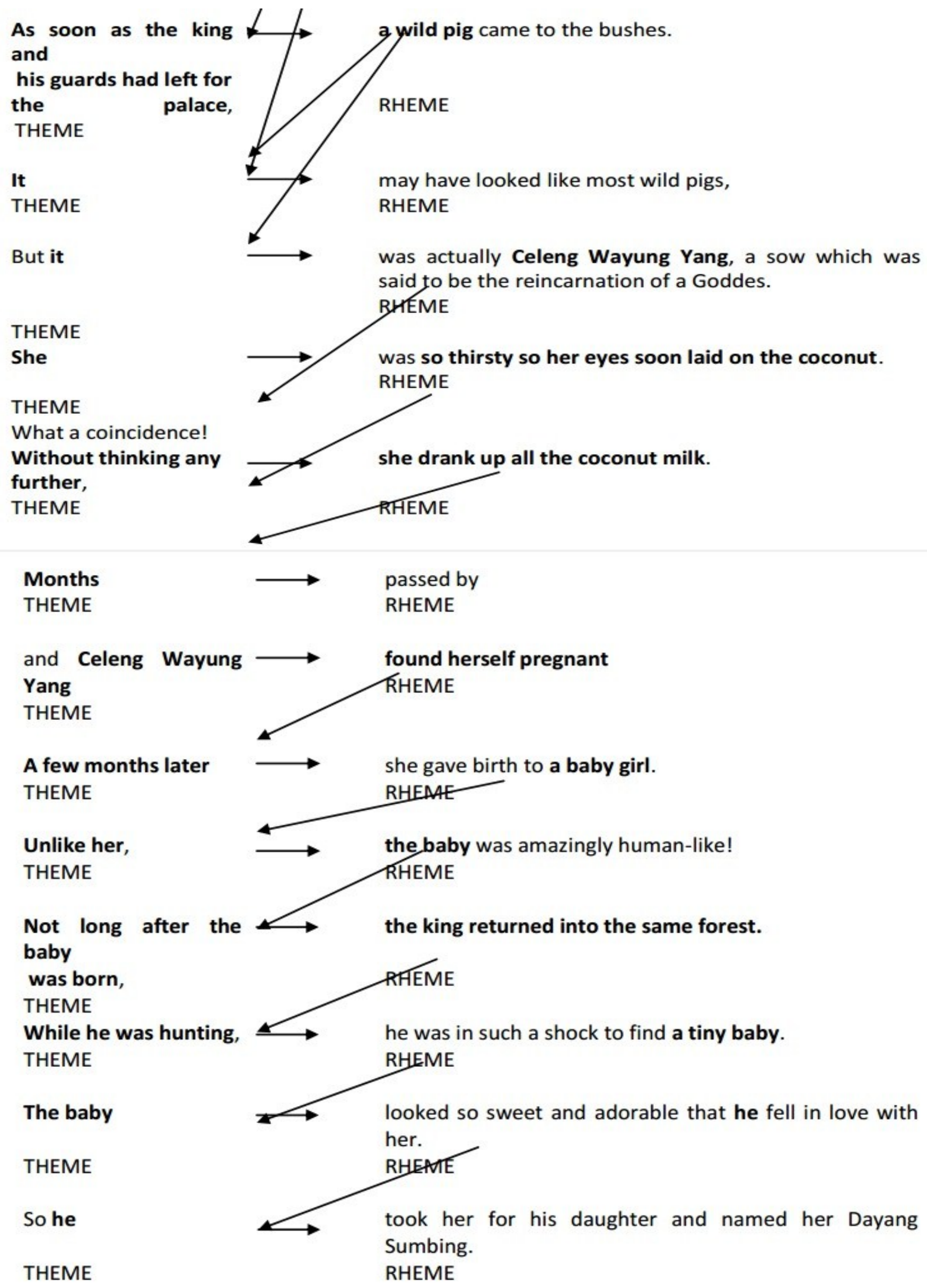

Not long after the $\longrightarrow$ the king returned into the same forest.

RHEAAE RHEME

he was in such a shock to find a tiny baby.

looked so sweet and adorable that he fell in love with her.

RHEATE 
The analysis of information flow in RHEME Themes for the above illustration is as follows:

- Themes in the following sentences are taken from RHEME previous sentences. For example, the topical theme is unmarked in the phrase 'Not only was he famous for his wisdom but also for his love of hunting' in acu from RHEME the previous sentence 'Hundreds of years ago, the Galuh kingdom in West Java, was ruled by a king of great wisdom namely King Prabu Sungging Perbangkara.'

- The previous sentence does not necessarily have the right sentence above it without a hose, but it can also be a sentence with one or two previous intervals. For example, in the phrase 'So he found himself bushes where a coconut laid under unnoticed and accidentally peed on the coconut', the unpublished topical theme 'he' refers to RHEME of two previous sentences namely 'the Galuh kingdom in West Java, was ruled by a king of great wisdom namely King Prabu Sungging Perbangkara '; in this case 'he' refers to 'Prabu Sungging Perbangkara' which functions as a RHEME. Likewise in the phrase 'As soon as the king and his guards had left for the palace', this theme is taken from the previous four sentences RHEME is' along with some of his guards he explored the hunting grounds of all the kingdom of prairies, forests, hills, mountains, valleys to steep slopes'.

- From the identification of the information flow in the theme-RHEMEas as illustrated above, it can be seen the integration between sentences in the Bsu text. The integration is illustrated by the direction of the arrow as the flow of information that follows from Theme to RHEME to Theme to RHEME, and so on so as to form the Theme-RHEME-Theme pattern.

\section{Conclusion}

1) Before the translation activities are carried out, the analysis needs to be done not only on the structure of the sentence but also on the information structure as reflected in the theme-rheme relation. Even the structure of information is not only known at the level of the sentence but also on the level of the paragraph.

2) Good translators have an awareness of the integration of paragraphs through the Theme-Rheme relationship. If the transla- tor does not maintain that alignment in the translation, the style and value of the textual cohesiveness of the target language will change.

\section{Acknowledgment}

I would like to thank STMIK AMIKOM Purwokerto which has supported the implementation of this research to complete.

\section{References}

[1] Wiratno, T. (2009). Makna Metafungsional Teks Ilmiah dalam Bahasa Indonesia pada Jurnal Ilmiah: Sebuah Analisis Sistemik Fungsional (Disertasi). Surakarta: Program Pascasarjana Universitas Sebelas Maret. Unpublished.

[2] Bell, R.T (1991). Translation and Translating: Theory and Practice. London: Longman Group UK.

[3] Halliday, M.A.K. (1997). Systemic Functional Grammar: A First Step into The Theory. Unpublished.

[4] Wiratno, T. (2009). Makna Metafungsional Teks Ilmiah dalam Bahasa Indonesia pada Jurnal Ilmiah: Sebuah Analisis Sistemik Fungsional (Disertasi). Surakarta: Program Pascasarjana Universitas Sebelas Maret. Unpublished.

[5] Moleong, L.J. (2013). Metodologi penelitian kualitatif: edisi revisi. Bandung: Remaja Rosdakarya.

[6] Newmark, P. (1988). A textbook of translation. London: Prentice Hall.

[7] Sangkuriang. Bandung: Nexx Media Inc. 